\title{
PELAKSANAAN PROGRAM PENGEMBANGAN INTELEKTUAL BAGI SISWA DI ASRAMA MAN 2 BOYOLALI
}

\author{
M. Ghofar Ismail, Siti Khoiriyah \\ IAIN Surakarta \\ ghofarjawa@gmail.com
}

\begin{abstract}
The purpose of this study was to determine the implementation of intellectual development programs for students in the dormitory of MAN 2 Boyolali. This research used a qualitative descriptive approach which was conducted in March-June 2017 at the MAN 2 Boyolali Dormitory. Collecting data using the method of observation, interviews and documentation. The results of this study can be concluded as follows: (1) The implementation of the intellectual development program is carried out for boarding students of MAN 2 Boyolali. (2) Types of intellectual development programs: Foreign language development through Muhadhoroh, FTMP, General Sciences. (3) Using modern constructivist intellectual development methods, CTL, GLC, in addition to modern methods equipped with modern media to keep up with the times and supporting infrastructure (4) For example, at FTMP, students are asked to find and present a short story, and make short stories , making articles, opinions, editing a work, then exposing it on the internet and looking for many who comment or comment, write poetry, fiction and non-fiction, what stands out is scientific writing, until students in the dormitory win the writing of high school level scientific papers in Boyolali district. So that students in the dormitory in carrying out scientific papers are not so difficult. The implementation of intellectual development programs for students in dormitories has a positive effect on MAN 2 Boyolali.
\end{abstract}

Keywords : Intellectual Development Program, Students, Dormitories 


\begin{abstract}
Abstrak
Tujuan penelitian ini adalah untuk mengetahui pelaksanaan program pengembangan intelektual bagi siswa di asrama MAN 2 Boyolali. Penelitian ini menggunakan pendekatan deskriptif kualitatif yang dilaksanakan pada bulan maret-juni 2017 di Asrama MAN 2 Boyolali. Pengumpulan data menggunakan metode observasi, wawancara dan dokumentasi. Hasil penelitian ini dapat disimpulkan sebagai berikut: (1) Pelaksanaan program pengembangan intelektual dilaksanakan untuk siswa asrama MAN 2 Boyolali. (2) Jenis-jenis program pengembangan intelektual: Pengembangan Bahasa asing melalui muhadhoroh, FTMP, Ilmu Umum. (3) Menggunakan metode pengembangan intelektual secara modern konstruktivisme, CTL, GLC, selain metode modern dilengkapi dengan media yang modern demi mengikuti perkembangan zaman dan sarana prasarana yang mendukung (4) Misalkan pada FTMP, siswa disuruh mencari dan mempresentasikan suatu cerpen, dan membuat cerpen, membuat artikel, opini, mengedit suatu karya, lalu mengekspos di internet dan mencari banyak yang mengkomen atau mengelike, menulis puisi, fiksi dan non fiksi, yang menonjol adalah karya tulis ilmiah, hingga siswa di asrama menjuarai penulisan karya ilmiah tingkat SMA satu kabupaten Boyolali. Sehingga siswa di asrama dalam mengerjalan karya tulis ilmiah tak begitu kesulitan. Pelaksanaan program pengembangan intelektual bagi siswa di asrama berpengaruh positif untuk MAN 2 Boyolali.
\end{abstract}

Kata kunci : Program Pengembangan Intelektual, Siswa, Asrama

\title{
A. PENDAHULUAN
}

Menurut Abdullah yang paling berperan dalam merubah wajah dunia ini yaitu orang yang berilmu dan berintelektual, sebab kemajuan dalam bidang apapun telah menciptakan revolusi yang sangat cepat, dalam kondisi seperti ini seorang intelektual dapat berperan memberikan suatu arahan kini, esok dan masa depan. Sebab sejarah membuktikan faktor yang sangat dominan dalam melakukan perubahan dunia adalah kekuatan intelektual sesorang dan suatu bangsa dan negara. ${ }^{1}$

Mengingat pentingnya intelektual dalam membangun bangsa dan negara, maka negara yang maju dapat dipastikan kualitas intelektualnya bagus, di Indonesia sendiri sedang mengaca pada bangsa dan negara

${ }^{1}$ Idi Abdullah., Sosiologi Pendidikan (Individu, Masyarakat, dan

Pendidikan), (Jakarta: PT Raja Grafindo Persada, 2011), h. 30

PROGRESS - Volume 8, No. 2, Desember 2020 
yang maju dengan membentuk seseorang yang berintelektual, cerdas, berilmu. Sehingga kualitas intelektual yang dimiliki menjadikan negara Indonesia maju. Untuk membuat bangsa dan negara yang maju, salah satunya melalui pendidikan. ${ }^{2}$

Pendidikan merupakan suatu proses yang diperlukan untuk mendapatkan keseimbangan dan kesempurnaan dalam perkembangan individu maupun masyarakat. ${ }^{3}$ Pendidikan juga merupakan sebuah proses dengan metode-metode tertentu sehingga orang memperoleh pengetahuan, pemahaman, dan cara bertingkah laku yang sesuai dengan kebutuhan. ${ }^{4}$ Pendidikan merupakan usaha sadar dan terencana untuk mewujudkan suasana belajar dan proses pembelajaran agar peserta didik secara aktif mengembangkan potensi dirinya untuk memiliki kekuatan spiritual keagamaan, pengendalian diri, kepribadian, kecerdasan, akhlak mulia, serta keterampilan yang diperlukan dirinya, masyarakat, bangsa, dan negara".

Menurut Aly mengatakan jalur pendidikan merupakan wahana yang dilalui peserta didik untuk mengembangkan potensi diri dalam suatu proses pendidikan. ${ }^{5}$ Jalur pendidikan dalam Undang-undang nomor 20 tahun 2003 dibagi menjadi tiga yaitu formal, nonformal dan informal. Pendidikan formal adalah jalur pendidikan yang terstruktur dan berjenjang yang terdiri atas pendidikan dasar, peneidikan menengah dan pendidikan tinggi. Sedangkan pendidikan non formal yaitu jalur

2 Basyiruddin Usman, Metodologi Pembelajaran Agama Islam, (Jakarta: Ciputat Pers, 2002), h. 7

${ }^{3}$ Nurkholis, "Pendidikan dalam Upaya Memajukan Teknologi", Jurnal Kependidikan, Vol. 1, No. 1, November 2013, h. 22

${ }^{4}$ Muhammad Ichsan, "Psikologi Pendidikan dan Ilmu Mengajar", Jurnal Edukasi, Vol. 2, No. 1, Januari 2016, h. 65

${ }^{5}$ Hery Noer Aly, Ilmu Pendidikan Islam, (Jakarta: Logos, 1999), h. 99 
pendidikan diluar pendidikan formal yang dilaksanakan secara terstruktur dan berjenjang. Kemudian pendidikan informal adalah jalur pendidikan keluarga dan lingkungan. ${ }^{6}$ Dari penjelasan berikut maka pendidikan formal merupakan pendidikan yang diselenggarakan di sekolah-sekolah pada umumnya. Pendidikan nonformal merupakan pendidikan yang diselenggarakan di luar sekolah dan rumah. Pendidikan informal merupakan pendidikan yang diselenggarakan di lingkungan keluarga.

Pendidikan formal disebut pula madrasah. Madrasah merupakan sebuah lembaga pendidikan yang dirancang untuk pengajaran siswa atau murid di bawah pengawasan pendidik atau guru. Madrasah juga termasuk pendidikan umum yang berakar kuat dari partisipasi masyarakat selaras dengan identitas negara kesatuan dalam keragaman berdasarkan Ketuhanan Yang Maha Esa Sebagian besar negara memiliki sistem pendidikan formal yang umumnya wajib dalam upaya menciptakan anak didik yang mengalami kemajuan setelah mengalami proses melalui pembelajaran. ${ }^{7}$

Lembaga pendidikan berfungsi untuk meningkatkan mutu kehidupan serta sumberdaya manusia itu sendiri, baik sebagai individu maupun sebagai kelompok dalam kehidupan bermasyarakat. ${ }^{8}$ Salah satu bentuk lembaga pendidian madrasah yaitu pendidikan memadukan model asrama dengan sekolah umum. Menurut Ki Hajar Dewantoro Asrama

\footnotetext{
"Ibrahim Bafadhol, " Lembaga Pendidikan Islam di Indonesia”, Edukasi Islami, Vol. 6, No. 11, Januari 2017, h. 60 2006), h. 75

${ }^{7}$ Enung K Rukianti, Sejarah Pendidikan Islam, (Bandung: CV Pustaka Setia,

${ }^{8}$ Rochmad, "Aktualisasi Teknologi dalam Pembelajaran Pendidikan Agama Islam”, Progress, Vol. 8, No. 1, Juni 2020, h. 64 
adalah (pondok, pawiyatan, bahasa jawa) merupakan rumah pengajaran dan pendidikan yang dipakai untuk pengajaran dan pendidikan. ${ }^{9}$ Asrama merupakan tempat tinggal bagi siswa sekaligus untuk menimba ilmu di samping pendidikan regular. Dengan model asrama peserta didik mengikuti kegiatan yang ada di asrama dan di madrasah. ${ }^{10}$ Sistem pendidikan dengan pola asrama, mengharuskan peserta didik mengikuti kegiatan pendidikan reguler dari pagi sampai siang hari kemudian dilanjutkan dengan kegiatan pendidikan dengan nilai-nilai khusus pada sore hari dan malam hari. ${ }^{11}$

\section{B. METODE PENELITIAN}

Jenis penelitian ini termasuk penelitian kualitatif dan jenis penelitian lapangan (field research), yaitu penelitian yang bertujuan menganalisis dan menyajikan fakta secara sistematik tentang keadaan objek yang sebenarnya. ${ }^{12}$ Dalam penelitian ini lokasi berada di Asrama MAN 2 Boyolali.

Adapun tempat atau lokasi penelitian di Asrama MAN 2 Boyolali, Jl. Singoprono Utara No.13 Jaweng, Pelem, Simo, Boyolali. Adapun alasan penentuan lokasi penelitian, karena Asrama MAN 2 Boyolali menerapkan dan memiliki program pengembangan intelektual. Penelitian ini dilaksanakan pada bulan April s.d Juni 2017.

Penelitian ini menggunakan teknik pengumpulan data langkah yang paling strategis dalam penelitian, karena tujuan utama dalam penelitian

\footnotetext{
${ }^{9}$ Bisma Fajar Musthofa, Widi Suroto, Hari Yuliarso, “Asrama Mahasiswa di Surakarta (dengan Pendekatan Arsitektur Eko-Kultur Sebagai Solusi Hunian Sementara)", Jurnal Senthong, Vol. 2, No. 1, Januari 2019, h. 270

${ }^{10}$ Irfan Setiawan, Pembinaan dan Pengembangan Peserta Didik pada Institusi Berasrama, (Yogyakarta: CV Writing Evolution, 2003), h. 1

${ }^{11}$ Djuju Sudjana, Evaluasi Pendidikan Luar Sekolah, (Bandung: Remaja Rosdakarya, 2014), h. 43

12 Saiful Anwar, Metode Penelitian, (Jakarta: Pustaka Pelajar, 2011), h. 6 
adalah mendapatkan data. Dalam penelitian ini pengumpulan data dilakukan pada kondisi yang nyata, sumber data primer dan teknik pengumpulan data lebih banyak pada observasi, wawancara, dan dokumentasi. ${ }^{13}$ penelitian ini menggunakan ketiga-tiganya.

Penelitian ini menggunakan teknik analisi data. Analisis data adalah proses mencari dan menyusun secara sistematis data yang diperoleh dari hasil observasi, wawancara, dokumentasi, catatan lapangan, dan bahanbahan lain, sehingga mudah dipahami, sebagaimana yang telah dikembangkan oleh Bogman. ${ }^{14} \mathrm{Hal}$ ini sangat penting bagi kita untuk mengetahui sejauh mana data-data yang digunakan mendukung dalam penelitian tentang pengembangan intelektual di asrama MAN 2 Boyolali.

\section{HASIL DAN PEMBAHASAN}

1. Program Pengembangan Intelektual

Pada hakikatnya pengembangan adalah upaya pendidikan baik formal maupun non formal yang dilaksanakan secara sadar, berencana, terarah, teratur dan bertanggung jawab dalam rangka memperkenalkan, menumbuhkan, membimbing, mengembangkan suatu dasar kepribadian yang seimbang, utuh, selaras, pengetahuan, keterampilan sesuai dengan bakat, keinginan serta kemampuankemampuan, sebagai bekal atas prakarsa sendiri untuk menambah, meningkatkan, mengembangkan diri ke arah tercapainya martabat, mutu dan kemampuan manusiawi yang optimal serta pribadi mandiri. ${ }^{15}$ Intelektual adalah orang yang menggunakan kecerdasan

13 Sugiyono, Metode Penelitian Kuantitatif Kualitatif dan R\&D, (Bandung:

Alfabeta, 2012), h. 225

${ }^{14}$ Sugiyono, Metode Penelitian Kuantitatif Kualitatif dan R\&D, ......h. 244

15 Iskandar Wiryokusumo, Dasar-dasar pengembangan kurikulum, (Jakarta: Bumi Aksara, 2011), h. 93 
otaknya untuk bekerja, belajar, membayangkan, dan menjawab persoalan tentang berbagai gagasan atau ide. ${ }^{16}$ Dalam bukunya Suarni Mengatakan bahwa intelektual dapat didifinisikan sebagai kecakapan yang tinggi untuk berpikir. ${ }^{17}$

Pengembangan intelektual adalah suatu usaha yang dilakukan secara sadar, terencana, terarah untuk membuat atau memperbaiki orang cerdik dan pandai yang memiliki sikap hidup yang terus menerus meningkatkan kemampuan berpikirnya untuk mendapatkan pengetahuan atau memahami sesuatu. sehingga menjadi produk yang semakin bermanfaat untuk meningkatkan kualitas sebagai upaya untuk menciptakan mutu yang lebih baik. ${ }^{18}$

Asrama MAN 2 Boyolali berdiri sejak tahun ajaran 2011/2012 dengan sarana pembelajaran yang belum memadai hanya memiliki tujuan untuk memberikan fasilitas bagi siswa yang ruhamnya jauh. Berkembangnya asrama MAN 2 Boyolali sehingga memiliki tujuan membentuk siswa asrama yang berkompeten dengan mengembangkan potensi siswa asrama dibanding siswa pada umumnya, dengan fasilitas yang memadai dan sarana prasarana yang mendukung.

2. Tujuan dan Ruang Lingkup Pengembangan Intelektual

Menurut Gardner, tujuan dan ruang lingkup pengembangan intelektual dalam bukunya Suarni membentuk 7 kecerdasan intelektual, yang diantaranya:

a. Kecerdasan Linguistik-Verbal, Kemampuan yang menonjol adalah Mengerti urutan dan arti kata-kata, menjelaskan, mengajar,

\footnotetext{
${ }^{16}$ Fatmi Sarah, "Kebebasan Intelektual di Perpustakaan" , Jurnal Perpustakaan dan Informasi, Vol. 9, No. 9, Oktober 2015, h. 30

${ }^{17} \mathrm{Ni}$ Ketut Suarni, Metode Pengembangan Intelektual,......., h. 1

${ }^{18} \mathrm{Ni}$ Ketut Suarni, Metode Pengembangan Intelektual,......, h. 60
} 
bercerita, berdebat, humor, mengingat, menghafal, menulis, main drama, berpuisi, mahir perbendaharaan kata. Biasanya kedepan ditujukan untuk menjadi editor, penulis, pengarang jurnalis, sastrawan, penyiar, guru, dst.

b. Kecerdasan Matematis-Logis, Kemampuan yang menonjol adalah mengklasifikasi, mengkategirisasi, abtraksi, simbolisasi pemikiran induktif dan deduktif, menghitung, bermain angka, pemikiran ilmiah, silogisme. Biasanya kedepan ditujukan untuk menjadi logikus, matematikus, akuntan, saintis, teknisi, dst.

c. Kecerdasan Ruang atau Spatial Visual, Kemampuan yang menonjol adalah mengenal relasi benda-benda dalam ruang yang tepat, mempunyai persepsi yang tepat dari berbagai sudut, menggambar, melukis, mengkaligrafi. Biasanya kedepan ditujukan untuk menjadi pemburu, arsitek, dekorator, seniman, grafer, dst.

d. Kecerdasan Kinestik-Badani, kemampuan yang menonjol adalah mudah ekspresi dengan tubuh, mengkaitkan pikiran dengan tubuh, kemampuan main mimik, main drama, aktif bergerak, dst. Biasanya kedepan ditujukan menjadi aktor, atlet, penari, teknisi, dst.

e. Kecerdasan Musical, kemampuan untuk mengembangkan seerta mengekspresikan bentuk-bentuk music dan suara. Biasanya kedepan ditujukan untuk menjadi penyanyi, musikal, pencipta lagu.

f. Kecerdasan Interpersonal, kemampuan untuk menangkap dan membuat perbendaan dalam perasaan, intensi, motivasi terhadap orang lain. Biasanya kedepan ditujukan untuk menjadi konselor, psikolog, dokter, perawat. 
g. Kecerdasan Intrapersonal, kemampuan pengetahuan akan diri sendiri dan kemampuan untuk bertindak secara adaptif berdasar pengenalan diri, termasuk di dalamnya kemampuan berefleksi dan keseeimbangan diri. Biasanya kedepan ditujukan untuk menjadi penasihat, rohaniawan, filosof, pencipta karya ilmiah, dst. ${ }^{19}$

3. Metode Pengembangan Intelektual

Menurut Suarni Pengembangan intelektual dapat dibantu dengan berbagai cara sebagai berikut:

a. Metode Bermain / Outbound

Secara melembaga pengembangan kognitif peserta didik dapat ditempuh melalui bermain/ outbond. Pengembangan ini dapat ditempuh melalui kegiatan-kegiatan yang melatih motoric halus. Contohnya: menyusun benda, menggambar, melukis, menulis kaligrafi, outbond permainan diluar lapangan. Karena pengembangan intelektual tidak hanya dilakukan secara formal melalui kegiatan di dalam kelas saja, di luar kelas pula disebut sebagai pengembangan intelektual yaitu melatih sistem motorik kasar otak. Pengembangan intelektual ini dimaksudkan pengembangan afeksi/ afektif yang meliputi dua halyaitu:

perkembangan emosi dan perkembangan nilai moral. ${ }^{20}$

b. Metode Pengembangan Intelektual Secara Modern

Menurut Suarni mengatakan bahwa pengembangan intelektual secara modern dapat dilakukan dengan metode pembelajaran yang inovatif. Metode pembelajaran inovatif lahir dari adanya

\footnotetext{
${ }^{19}$ Ni Ketut Suarni, Metode Pengembangan Intelektual,......, h. 4

${ }^{20} \mathrm{Ni}$ Ketut Suarni, Metode Pengembangan Intelektual,......, h. 60
} 
keresahan terhadap cara belajar klasikal. Dimana peserta didik tidak dapat terlibat aktif dalam hal intelektual maupun fisik. Karena itu dirancanglah sebuah metode pembelajaran yang bisa mengaktifkan seluruh indera dan intelektualitas peserta didiknya. ${ }^{21}$ Metode pengembangan yang termasuk dalam metode pembelajaran inovatif adalah pembelajaran berbasis elektronik dan contextual learning meliputi:

1) Model Pembelajaran Berbasis Elektronik (E-learning). Elearning merupakan salah satu bentuk model pembelajaran yang difasilitasi dan didukung pemanfaatan teknologi informasi dan komunikasi.E-learning dalam kegiatan belajar mengajar menggunakan jasa bantuan perangkat elektronika seperti audio, video atau perangkat computer atau kombinasi dari ketiganya. E-learning tidak harus On-line melalui website akan tetapi juga bisa melalui Off-line. Disebtu melalui off-line bisa melaui CD/DVD dan sebagainya. Selain itu tugas-tugas peserta didik bisa dikirim lewat website ini adalah termasuk metode pengembangan intelektual melalui secara modern.

2) Model Pembelajaran Berbasis Konteks (Contextual and Teaching Learning (CTL)) Fenomena pembelajaran yang berkembang di lapangan adalah masih banyak pengajar yang mengajar hanya sekedar menyelesaikan materi tanpa memikirkan apakah yang diberikanya itu bermakna atau ada keterkaitan dengan dunia nyata. Yang menjadi penyebab

\footnotetext{
${ }^{21}$ Ni Ketut Suarni, Metode Pengembangan Intelektual,......, h. 63
} 
seperti ini adalah harus menyelesaikan materi yang cukup banyak tetapi waktu kurang. ${ }^{22}$

Beranjak dari fenomena itulah pembelajaran berbasis konteks atau CTL. Intinya CTL adalah pembelajaran yang menggabungkan isi/materi dengan pengalaman harian individu, kehidupan di dalam masyarakat dan alam seikitar. CTL merupakan konsep belajar yang membantu guru mengaitkan antara materi yang diajarkan dengan situasi dunia nyata siswa dan mendorong siswa membuat hubungan antara pengetahuan yang dimilikinya dengan penerapannya dalam kehidupan mereka sebagai anggota keluarga dan masyarakat. ${ }^{23}$ Diharapkan dengan CTL peserta didik dapat memahami materi secara konkrit. Dilakukan konkrit karena tangan dan "kepala" mereka ikut terlibat aktif dalam mempelajari dan memahami materi yang disampaikan. CTL mempunyai komponen-komponen yaitu: Konstruktivisme, Inquiry, Questioning (Bertanya), Learning Community Grup Belajar, Modeling (Pemodelan), Reflection (refleksi) dan Authentic assessment (penilaian yang sebenarnya).

4. Pelaksanaan Program Pengembangan Intelektual

Pelaksanaan program pengembangan intelektual bagi siswa asrama di asrama MAN 2 Boyolali sesuai dengan teori meliputi kecerdasan linguistic-verbal, kecerdasan kinestik-badani, kecerdasan ruang atau spatial visual, kecerdasan musical, dan kecerdasan intrapersonal. beberapa diantaranya adalah sebagai berikut:

\footnotetext{
${ }^{22}$ Sulistyo Numiek, “Keefektifan E-Learningsebagai Media Pembelajaran(Studi Evaluasi Model Pembelajaran E-Learningsmk Telkom Sandhy Putra Purwokerto)", Jurnal Pendidikan Vokasi, Vol. 3, No. 1, Desember 2013, h. 92

${ }^{23}$ Teguh Sihono, "Contextual Teaching And Learning (Ctl) Sebagai Model Pembelajaran Ekonomi Dalam Kbk", Ekonomi dan Pendidikan, Vol. 1, No. 1, Februari 2004, h. 84
} 
a. Pengembangan Bahasa Asing melalui Muhadhoroh. Pengembangan bahasa asing melalui muhadhoroh adalah suatu rangkaian kegiatan atau proses, dalam rangka mencapai suatu tujuan tertentu. Tujuan ini dimaksudkan untuk memberi arah atau pedoman bagi gerak langkah kegiatan dakwah dengan cara berpidhato menggunakan bahasa asing, yang meliputi bahasa Arab dan bahasa Inggris dengan nama yang sama yaitu muhadhoroh. Pengembangan intelektual disini yang dikembangkan yaitu kecerdasan linguistic-verbalnya. ${ }^{24}$

1) Bentuk kegiatan

Kegiatan muhadhoroh adalah kegiatan mengasah siswa asrama dalam mengolah kata dalam bentuk bahasa asing, dalam pelaksanaanya siswa ketika muhadhoroh tidak diperkenankan membaca teks yang telah dibuat dihadapan teman-temanya yang mendengarkan. Sebelum acara muhadhoroh dimulai diiringi dengan $\mathrm{MC}$ / Pembawa acara yang menyampaikanya menggunakan bahasa asing dilanjutkan dengan membaca lantunan ayat suci Al-Quran dan di akhiri dengan muhadhoroh.

Dalam pelaksanaanya kegiatan muhadhoroh ini siswa di asrama dibagi menjadi beberapa kelompok setiap kelompok terdiri dari 5 peserta dengan ketentuan 3 peserta untuk muhadhoroh 1 peserta untuk MC/ Pembawa acara dan 1 peserta untuk tilawatul Quran atau membaca lantunan ayat suci Al-Quran. Pada awal mulanya untuk peserta muhadhoroh diberikan mufrodat atau 
vocabulary oleh seksi lughoh atau seksi bahasa di dalam asrama pada pagi hari. Kemudian peserta muhadhoroh merangkai kosakata tersebut sehingga menjadi teks muhadhoroh yang lengkap. Sedangkan untuk peserta MC/ Pembawa acara tidak diberikan kosakata sehingga diberikan suatu kebebasan dalam menyusun susunan acara sesuai kesepakatan pada suatu kelompok. Kemudian untuk peserta tilawatul Quran diberikan suatu kebebasan dalam memilih ayat dan surat dalam Al-Quran. Dan dibacakan pada saat acara dimulai Kegiatan muhadhoroh ini bertujuan:

a) Melatih siswa asrama pandai berbicara di depan audiens dengan menggunakan bahasa asing

b) Melatih siswa asrama berbicara bahasa asing tanpa berfikir atau menghafal terlebih dahulu

c) Melatih siswa dalam membawa acara yang benar dalam suatu acara tertentu

d) Melatih siswa melantunkan bacaan suci ayat Al-Quran di depan audiens

e) Melatih siswa dalam kecakapan berbicara ${ }^{25}$

2) Metode

Metode dalam kegiatan ini termasuk metode pengembangan intelektual secara modern sesuai teori yang digunakan. Metodenya yaitu menggunakan metode GLC (Group Learning Community) adalah metode membentuk kelompok dengan tugas masing-masing yang berbeda. Dengan bekerja sama

${ }^{25}$ Wawancara dengan Ibu Hamida Laili sebagai pembina asrama MAN 2 Boyolali, pada hari Rabu, 18 April 2017 
kelompok menjadi hidup. Dengan saling mengajari satu sama lain.

3) Metode dan Sarana Prasarana

Media dan sarana prasarana yang digunakan dalam kegiatan yaitu: Speaker, Alat Peraga Muhadhoroh, LCD Proyektor, Laptop, Masjid dan Kelas.

b. Forum Tulis Menulis Pelajar (FTMP)

Pengembangan intelektual selanjutnya yang dikembangakan yaitu kecerdasan intrapersonal sesuai dengan teori yang digunakan. Dalam kecerdasan ini melalui kegiatan FTMP (Forum Tulis Menulis Pelajar) adalah kegiatan siswa asrama dalam pengembangan tulis menulis fiksi dan non fiksi. Guna mengasah otak siswa asrama sehingga menjadi siswa yang pandai berbicara dan menulis.

1) Bentuk Kegiatan

Kegiatan FTMP adalah salah satu dari kegiatan di asrama MAN 2 Boyolali selain kegiatan keagamaan, sosial, olahraga. Dalam pelaksanaanya, kegiatan FTMP siswa membuat karya fiksi dan non fiksi.

Langkah pertama siswa asrama diberikan tema oleh pembina asrama. Kemudian siswa yang telah mendapat tema mencari contoh di internet sesuai tema yang telah diberikan, setelah mendapatkan apa yang dicari kemudian siswa mempelajari apa yang telah didapat dengan sendiri. Langkah selanjutnya siswa membuat karya seperti yang telah didapat dengan berbeda pembahasan. Setelah karya fiksi maupun non fiksi yang dibuat telah selesai, kemudian karya tersebut di ekspos di internet. 
Dengan seperti itu siswa menjadi lebih termotivasi dengan semakin banyak karya yang dilihat oleh netizen(Pengguna Internet), disukai oleh netizen, diakuisisi oleh netizen maka siswa tersebut yang mendapatkan nilai yang terbaik. Selain itu pula siswa mengutarakan pengalaman dalam bentuk tulisan seperti karya ilmiah, cerpen dan semacamnya. Dari sini siswa dilatih untuk menuangkan pengalaman menjadi kata-kata yang bersifat ilmiah dan dapat menjadi ilmu bagi pembacanya.

2) Metode FTMP (Forum Tulis Menulis Pelajar)

Metode yang digunakan dalam pengembangan intelektual ini menggunakan metode pengembangan intelektual secara modern dan bermain/outbond. Melalui metode E-Learning, CTL (Contekstual and Teaching Learning) dan Outbond.

Untuk metode E-Learning siswa menggunakan audio, visual, internet. Dalam kegiatan siswa tidak jauh dari laptop/pc atau elektronik lainya, yang menjadikan siswa lebih dinamis dalam menulis.

Untuk Menggunakan metode CTL (Contekstual and Teaching Learning) pembina asrama tidak hanya memberikan materi saja, tanpa ada tindak lanjut dari materi tersebut, sehingga dihubungkan dengan kenyataan atau pengalaman yang dialami oleh siswa dan kejadian di lingkungan sekitar. Sedangkan untuk Outbond yaitu salah satu cara untuk membuat siswa asrama tidak jenuh di dalam asrama berharihari. Selain untuk menjernihkan pikiran, outbond untuk pembelajaran diluar kaitanya dengan menulis karya ilmiah siswa maka siswa dapat melakukannya dengan metode 
observasi apa yang di lihat pada saat outbond. Pembina asrama memberikan kebebasan bagi siswa untuk bermain/outbond sebagai langganan untuk tempat outbond yaitu hutan di simo, yang dapat digunakan sebagai bahan untuk menulis suatu karya ilmiah dari tempat tersebut.

3) Media dan Sarana Prasarana

Media dan Sarana Prasarana yang digunakan adalah laptop, internet, ruang kelas, dan masjid. ${ }^{26}$

c. Kegiatan Tambahan Pengembangan Intelektual

Pengembangan intelektual selanjutnya mengembangkan kecerdasan spatial visual, kecerdasan kinestik-badani, kecerdasan musical. Untuk mengembangkan intelektual nilai seni siswa asrama memberikan kegiatan berupa kaligrafi, melukis, olahraga, hadrah dan band. Kecerdasan spatial visual, kecerdasan kinestik-badani, kecerdasan musical dinilai penting dikembangkan untuk mengembangkan potensi yang dimiliki oleh siswa di asrama MAN 2 Boyolali.

Berdasarkan hasil pengamatan saya pada para siswa asrama menggambar pada waktu sore hari dengan didampingi oleh pembina asrama yang diwakili oleh guru seni budaya MAN 2 Boyolali. Dalam kurun waktu 90 menit siswa menggambar bebas baik kaligrafi maupun gambar umum hasil yang dicapai oleh siswa menurut pengamatan peneliti mempunyai potensi yang perlu dikembangkan. ${ }^{27}$

${ }^{26}$ Wawancara dengan Ibu Hamida Laili sebagai pembina asrama MAN 2 Boyolali, pada hari Rabu, 18 April 2017

${ }^{27}$ Observasi secara langsung di asrama MAN 2 Boyolali, pada hari Minggu, 15 April 2017 
5. Prestasi dari Pelaksanaan Program Pengembangan Intelektual Pelaksanaan program pengembangan intelektual berpengaruh bagi MAN 2 Boyolali. Siswa di asrama MAN 2 Boyolali mendapatkan prestas dengani membawa nama harum MAN 2 Boyolali. Atas hasil terbaru dari program tersebut, tercatat sebagai berikut:

a. Anggia Primaswari

Juara Lomba Pidhato Bahasa Arab Tingkat SMA/MA Se-Soloraya 2017

b. Ahmad Syaiful

Juara karya tulis ilmiah tingkat SMA/MA Se-Kab Boyolali 2017 dengan judul "Budidaya Tanaman Hidroponik di Pekarangan Hutan Desa Wonosemar Simo Boyolali”

c. Nur Sucy Lestari

Juara Lomba Pidhato Bahasa Inggris Tingkat SMA/MA SeSoloraya 2017

d. Hadrah Al-Ittihad Juara Festival Hadrah Se-Soloraya \& DIY

\section{KESIMPULAN}

Berdasarkan data serta analisis yang telah dilakukan, maka dapat diambil kesimpulan sebagai berikut:

1. Pelaksanaan Program Pengembangan Intelektual Berdasarkan intrepetasi hasil penelitian dapat disimpulkan bahwa pelaksanaan program pengembangan intelektual bagi siswa di asrama MAN 2 Boyolali mepunyai tujuan menjadikan siswa yang unggul dalam bidang keagamaan dan umum, menjadikan siswa yang memiliki kecakapan berbicara, menjadikan siswa yang memiliki kecakapan menulis, menjadikan siswa yang berprestasi akademik dan non akademik, menjadikan output yang berkompeten, menjadikan 
produk yang bermanfaat. Waktu pelaksanaan program pengembangan intelektual dilakukan pada kelas sore, malam dan pagi hari.

2. Program Pengembangan Intelektual

Program pengembangan intelektual di asrama MAN 2 Boyolali meliputi kecerdasan linguistik-vebal, spatial-visual, intrapersonal. Yang terdiri dari program pengembangan bahasa asing, FTMP dan program umum. Pada program pengembangan bahasa asing mencakup muhadhoroh, MC dan qiroah. Sedangkan pada program FTMP mencakup karya ilmiah, fiksi dan non fiksi.

3. Metode Pengembangan Intelektual

Program pengembangan intelektual di asrama MAN 2 Boyolali menggunakan metode GLC (Group Learning Community), metode CTL (Contekstual and Teaching Learning) dan metode E-Learning sesuai dengan teori dari Ni Ketut Suarni tentang metode yang digunakan oleh program pengembangan intelektual. 
Jurnal Pendidikan Agama Islam Universitas Wahid Hasyim Semarang

\section{DAFTAR PUSTAKA}

Abdullah, Idi., Sosiologi Pendidikan (Individu, Masyarakat, dan Pendidikan), Jakarta: PT Raja Grafindo Persada, 2011

Afrizal, Dimas dan Maulana, Aslich, "Implementasi Kegiatan Muhadhorohdalam Menumbuhkan Life Skillsiswa Smk Muhammadiyah 2 Gresik", Tamaddun, Vol. 19, No. 1, Januari 2018

Ali, Hery Noer., Ilmu Pendidikan Islam, Jakarta: Logos, 1999

Anwar, Saiful., Metode Penelitian, Jakarta: Pustaka Pelajar, 2011

Bafadhol, Ibrahim, "Lembaga Pendidikan Islam di Indonesia”, Edukasi Islami, Vol. 6, No. 11, Januari 2017

Ichsan, Muhammad, “Psikologi Pendidikan dan Ilmu Mengajar”, Jurnal Edukasi, Vol. 2, No. 1, Januari 2016

Musthofa, Bisma Fajar. Suroto, Widi.Yuliarso, Hari, “Asrama Mahasiswa di Surakarta (dengan Pendekatan Arsitektur Eko-Kultur Sebagai Solusi Hunian Sementara)", Jurnal Senthong, Vol. 2, No. 1, Januari 2019

Numiek, Sulistyo, "Keefektifan E-Learningsebagai Media Pembelajaran(Studi Evaluasi Model Pembelajaran E-Learningsmk Telkom Sandhy Putra Purwokerto)", Jurnal Pendidikan Vokasi, Vol. 3, No. 1, Desember 2013

Nurkholis, "Pendidikan dalam Upaya Memajukan Teknologi", Jurnal Kependidikan, Vol. 1, No. 1, November 2013

Rochmad, "Aktualisasi Teknologi dalam Pembelajaran Pendidikan Agama Islam", Progress, Vol. 8, No. 1, Juni 2020

Rukianti, Enung K., Sejarah Pendidikan Islam, Bandung: CV Pustaka Setia, 2006 
Jurnal Pendidikan Agama Islam Universitas Wahid Hasyim Semarang

Sarah, Fatmi, "Kebebasan Intelektual di Perpustakaan", Jurnal Perpustakaan dan Informasi, Vol. 9, No. 9, Oktober 2015

Setiawan, Irfan., Pembinaan dan Pengembangan Peserta Didik pada Institusi Berasrama, Yogyakarta: CV Writing Evolution, 2003

Sihono, Teguh, "Contextual Teaching And Learning (Ctl) Sebagai Model Pembelajaran Ekonomi Dalam Kbk", Ekonomi dan Pendidikan, Vol. 1, No. 1, Februari 2004

Suarni, Ni Ketut., Metode Pengembangan Intelektual, Yogyakarta: Graha Ilmu, 2014

Sudjana, Djuju., Evaluasi Pendidikan Luar Sekolah, Bandung: Remaja Rosdakarya, 2014

Sugiyono., Metode Penelitian Kuantitatif Kualitatif dan R\&D, Bandung: Alfabeta, 2012

Usman, Basyiruddin., Metodologi Pembelajaran Agama Islam, Jakarta: Ciputat Pers, 2002

Wiryokusumo, Iskandar., Dasar-dasar pengembangan kurikulum, Jakarta: Bumi Aksara, 2011. 